\title{
PLANT GROWTH OF CURLY KALE UNDER SALINITY STRESS
}

\author{
Piotr Salachna ${ }^{1}$, Rafał Piechocki', Andżelika Byczyńska' \\ 1 Department of Horticulture, West Pomeranian University of Technology in Szczecin, Papieża Pawła VI 3 Str., 71 - \\ 459 Szczecin, Poland, e-mail: piotr.salachna@zut.edu.pl, rafal.piechocki@zut.edu.pl, andzelika.woskowiak@ \\ zut.edu.pl
}

Received: 2016.08.01 Accepted: 2016.10 .23 Published: 2017.01.01

\begin{abstract}
Ornamental plants growing in urban areas are exposed to soil salinity that negatively affects their quality. Identifying species that retain high ornamental value despite salt stress is therefore of high practical importance. Curly kale (Brassica oleracea L. var. sabellica L.) is an attractive plant with leaves of both edible and ornamental character. The aim of the study was to evaluate a response of ornamental curly kale to different concentrations of $\mathrm{NaCl}$. The study material was 'Scarlet' cultivar. The plants were grown in pots in a plastic tunnel. They were irrigated with $\mathrm{NaCl}$ solution at the following concentrations: 50, 100, 200, 400, and $800 \mathrm{mM} \mathrm{mmol} \cdot \mathrm{dm}^{-3} \cdot \mathrm{NaCl}$ treatment resulted in a significant increase in $\mathrm{pH}$ and electrical conductivity (EC) of the substrate. Salt stress significantly affected plant growth and number, width and length of leaves, and the effects depended on $\mathrm{NaCl}$ concentration. Fifteen days after the salt supply ceased, relative chlorophyll content in leaves (SPAD) decreased due to $\mathrm{NaCl}$ treatment in a concentration-dependent manner. Treatments with 200, 400 , and $800 \mathrm{mmol} \cdot \mathrm{dm}^{-3} \mathrm{NaCl}$ reduced stomatal conductance, and the changes were greater on the 5 th day following the stress cessation than on the 15 th day. Irrigation with a 200,400 , and $800 \mathrm{mmol} \cdot \mathrm{dm}^{-3} \mathrm{NaCl}$ solution negatively affected plant bonitation score. The plants treated with 50 i $100 \mathrm{mmol} \cdot \mathrm{dm}^{-3} \mathrm{NaCl}$ were not significantly different visual score from the control plants.
\end{abstract}

Keywords: sodium chloride, ornamental plants, stomatal conductance, SPAD

\section{INTRODUCTION}

Ornamental plants growing in urban areas should be resistant to air pollution and soil salinity [Pląskowska, 2010]. Soil salinity along city transportation routes is due to human activity, such as using sodium chloride to remove snow from roads, streets, and pavements [Bach et al., 2009]. Salt concentrations that exceed plant tolerance level cause growth inhibition [Villarino and Matsson, 2011], reduce flower quality [Sonneveld et al., 1999], trigger leaf browning and drying [Cassaniti et al., 2012], and finally result in plant organ death [Niu and Cabrera, 2010; Parihar et al., 2015]. Salinity has a negative impact on photosynthesis [Vetach-Blohm et al., 2013], water management [Ma et al., 2012] and enzymatic activity [Zhang et al., 2014]. It also disturbs nutrient absorption and ion balance [Valdez-Aguilar et al., 2009], induces osmotic stress [Munns and Tester, 2008] and dysfunction of plasma membranes [Mansour et al., 2015]. Plant responses to salinity are variable and depend on plant genotype, growth phase and soil moisture content [Niu and Cabrera, 2010; Cassaniti et al., 2013]. Recent years witnessed numerous research studies on the sensitivity of different species of ornamental plants to salinity that were aimed at identifying the plants tolerant to excess soil salt and estimating the degree of this tolerance [Niu et al. 2007; Niu and Cabrera 2010; Breś et al., 2014; Sun et al., 2015; Wu et al., 2016]. Learning more about salt tolerant plants is of great practical importance in the selection of species and cultivars grown in urban green areas [Niu et al., 2010; Cassaniti et al., 2013; Escalona et al., 2013; Salachna and Piechocki, 2016]. 
Ornamental cultivars of vegetables planted in flowerbeds are currently highly valued [Gibson and Whipker, 2001; Zhao and Li, 2011; Haghighi et al., 2016]. Curly kale (Brassica oleracea L. var. sabellica L.), cultivated already in ancient Greece and Rome for ornamental and food purposes, is a good example of such a species [Murray et al. 2005]. Its plants produce thick stems with curly leaves arranged in a characteristic rosette. Kale leaves are edible and decorative, and depending on the cultivar they can be less or more curly, dark green to purple brown [Lewandowska 2000]. Their colors turn very bright after the first light freezes. The plants grow rapidly and have low soil requirements. Curly kale can be successfully cultivated in flowerbeds and pots [Hirvela 2014]. Due to its high resistance to low temperature curly kale is also highly decorative in autumn and winter [Watson, 1996].

Most studies on the response to salt stress conducted in ornamental plants of Brassicaceae family concerned ornamental cabbage and kale (Brassica oleracea var. acephala). Chen et al. [2011] proved that germination of ornamental cabbage seeds depended on the cabbage cultivar and $\mathrm{NaCl}$ concentration. In 'Nagoya series' cv., salt tolerance was the highest (lethal concentration $213.65 \mathrm{mmol} / \mathrm{L} \mathrm{NaCl}$ ), while in 'Pigeons series' it was the lowest (lethal concentration $87.32 \mathrm{mmol} / \mathrm{L}$ ). Zheng et al. [2010] reported that rising doses of $\mathrm{NaCl}$ first increased and then decreased the content of soluble protein and CAT and POD activity in ornamental kale seedlings. They claimed that the content of soluble protein and CAT activity were the highest when $\mathrm{NaCl}$ concentration was $600 \mathrm{mmol} / \mathrm{L}$, while POD activity reached its highest level at $800 \mathrm{mmol} / \mathrm{L} \mathrm{NaCl}$. According to Haghighi et al. [2016], ornamental kale is recommended for phytoremediation of saline soils with 10 and $16 \mathrm{mg} \cdot \mathrm{kg}^{-1}$ lead and cadmium contents, respectively.

So far, scientific literature lacks papers on the effects of salinity in ornamental curly kale cultivars. Therefore, the aim of this study was to evaluate the effects of moderate soil salinity caused by sodium chloride on morphological features, stomatal conductance, greenness index of leaves and ornamental value of curly kale.

\section{MATERIAL AND METHODS}

Curly kale (Brassica oleracea L. var. sabellica L.) plants of 'Scarlet' cv. (purple leaves) were derived from seedlings produced in a heated greenhouse. The seeds obtained from Breeding and Seed Company W. Legutko (Poland) were sown on 30th March 2015, and after 2 weeks the seedlings were transferred into pots $8 \mathrm{~cm}$ in diameter, filled with TS1 plant substrate (KlasmannDeilmann, Poland). On 6th May 2015, single seedlings were transferred into black PCV pots of $17 \mathrm{~cm}$ diameter and $2 \mathrm{dm}^{3}$ capacity. The substrate was deacidified peat with $\mathrm{pH} 6.5$ mixed with Yara Mila Complex fertilizer (Yara International ASA, Norway) containing $12 \% \mathrm{~N}, 11 \% \mathrm{P}_{2} \mathrm{O}_{5}, 18 \% \mathrm{~K}_{2} \mathrm{O}$, $2.7 \% \mathrm{MgO}, 8 \% \mathrm{~S}, 0.015 \% \mathrm{~B}, 0.2 \% \mathrm{Fe}, 0.02 \% \mathrm{Mn}$ and $0.02 \% \mathrm{Zn}$, used at $3 \mathrm{~g} \cdot \mathrm{dm}^{-3}$. The pots were placed on $60 \mathrm{~cm}$ high tables in an unheated tunnel covered with double layer of plastic located in the area of West Pomeranian University of Technology in Szczecin $\left(53^{\circ} 25^{\prime}\right.$ N, $1^{\circ} 32^{\prime}$ E; 25 $\mathrm{m}$ a.s.1.). The temperature inside the tunnel was monitored by vents that opened automatically when the temperature exceeded $20^{\circ} \mathrm{C}$. The plants were irrigated with a solution of pure p.a. $99.9 \%$ sodium chloride $(\mathrm{NaCl})$ (Chempur, Poland). The irrigation started on 27th May 2015 and the following $\mathrm{NaCl}$ concentrations were used: 50, 100, 200,400 , and $800 \mathrm{mmol} \cdot \mathrm{dm}^{-3}$. Salt treatment was repeated four times, every 5 days, using $300 \mathrm{ml}$ of the solution per plant. Control plants were irrigated with tap water with $\mathrm{EC} 0.27 \mathrm{mS} \cdot \mathrm{cm}^{-1}$. Five and fifteen days after the last treatment, two physiological parameters, i.e. greenness index and stomatal conductance were assessed. The greenness index (relative chlorophyll content) was measured in SPAD units (Soil Plant Analysis Development) with an optical device Chlorophyll Meter SPAD-502 (Minolta, Japan). The measurements included five leaves located in the central section of the plant and three readings were taken per each leaf. Stomatal conductance $\left(g_{\mathrm{s}}\right)$ was assessed with $\mathrm{SC} 1$ porometer (Dekagon Devices, USA). The measurements were conducted from 10:00 a.m. to 12:00 p.m. and included three leaves from each plant. PAR radiation during measurement was $910-1033 \mu \mathrm{mol} \cdot \mathrm{m}^{-2} \cdot \mathrm{s}^{-1}$ (as per Radiometer-Fotometr RF-100, Snopan, Poland). The plants were grown under natural photoperiod till 15th July 2015. On the last day of the experiment, the following parameters were determined: plant height, number of leaves per plant, length and width of the largest leaf from the central section of the plant. The visual score of the plants was assessed by three people according to the bonitation scale from 1 to 5 points, where 5 meant the plants of the highest quality. In each variant of 
the experiment, three replications of the substrate sample were taken in order to determine $\mathrm{pH}$ and electrical conductivity (EC). The measurements were performed with microcomputer $\mathrm{pH}-\mathrm{METER}$ CP-315 M (Elmetron, Poland) and conductivity meter CC-411 (Elmetron, Poland), in aqueous extract (substrate : distilled water $1: 2$ ).

Each experimental variant included 20 plants, 5 plants per repetition. The results were statistically evaluated by the analysis of variance (ANOVA) for univariate experiments. Statistical software ANALWAR-4.3, (based on Microsoft Excel) developed by Franciszek Rudnicki was used. Mean values were compared using Tuckey test for a significance level $\alpha=0.05$.

\section{RESULTS AND DISCUSSION}

Analysis of the substrate after the experiment completion revealed a significant increase in $\mathrm{pH}$ and electrical conductivity (EC) as a result of $\mathrm{NaCl}$ administration (Table 1). The increased $\mathrm{pH}$ may be due to alkalizing properties of $\mathrm{NaCl}$, mainly sodium, which trigger the following se-

Table 1. The $\mathrm{pH}$ and electrical conductivity (EC) of growing medium solution in the end of experiment

\begin{tabular}{|c|c|c|}
\hline $\mathrm{NaCl}\left(\mathrm{mmol} \cdot \mathrm{dm}^{-3}\right)$ & $\mathrm{pH}$ & $\mathrm{EC}\left(\mu \mathrm{S} \cdot \mathrm{cm}^{-1}\right)$ \\
\hline 0 & $6.72 \pm 0.03$ & $47.0 \pm 4.90$ \\
\hline 50 & $7.07 \pm 0.08$ & $243 \pm 6.55$ \\
\hline 100 & $7.29 \pm 0.03$ & $327 \pm 6.60$ \\
\hline 200 & $7.38 \pm 0.07$ & $385 \pm 4.50$ \\
\hline 400 & $7.41 \pm 0.02$ & $565 \pm 4.50$ \\
\hline 800 & $7.45 \pm 0.03$ & $621 \pm 7.75$ \\
\hline $\mathrm{LSD}_{0.05}$ & 0.135 & 15.598 \\
\hline
\end{tabular}

ries of reactions: $\mathrm{NaCl} \rightarrow \mathrm{NaHCO}_{3} \rightarrow \mathrm{Na}_{2} \mathrm{CO}_{3}$ $\rightarrow \mathrm{NaOH}$ [Breś, 2008]. High pH disturbs absorption of phosphorus and most of the micronutrients [Marschner, 1995], which could induce discoloration and necrosis of leaves in the plants treated with the highest concentration of $\mathrm{NaCl}$, i.e. 400 and $800 \mathrm{mM}$ (Fig. 1). Plant injury could result from increasing ion concentrations that cause chlorosis and necrosis on the leaf margins and premature leaf fall [Cassaniti et al., 2012].

Table 2 presents the effect of $\mathrm{NaCl}$ on stomatal conductance $\left(g_{s}\right)$ in the leaves of 'Scarlet' cv. In plants treated with low concentration of $\mathrm{NaCl}$, i.e. 50 and $100 \mathrm{mmol} \cdot \mathrm{dm}^{-3}$, this parameter was not significantly different from the control plants five and fifteen days after the stress cessation. Significant reduction in stomatal conductance was observed in the plants treated with 200,400, and $800 \mathrm{mmol} \cdot \mathrm{dm}^{-3} \mathrm{NaCl}$, particularly five days after the last $\mathrm{NaCl}$ dose. Significant reduction in this physiological parameter due to salt stress was observed in previous studies in Chrysanthemum $\times$ morifolium 'Yellow Blush' [Lee and van Iersel, 2008], Narcissus 'Dutch Master' and 'Tete-eTete' [Vetach-Blohm et al., 2013], and Plectranthus ciliatus E.Mey. ex Benth. [Salachna et al., 2015]. Stomatal conductance is an important indicator of stomatal control of water loss and $\mathrm{CO}_{2}$ assimilation. Lowered stomatal conductance in plants exposed to salt stress may be due to a reduction in water potential or disturbances in photosynthesis and respiration [Parihar et al., 2015].

Changes in relative chlorophyll content in the leaves of 'Scarlet' cv. exposed to salt stress are presented in Table 3. Five days after the last salt application, the plants treated with the highest $\mathrm{NaCl}$ concentrations (400 and $800 \mathrm{mmol} \cdot \mathrm{dm}^{-3}$ )

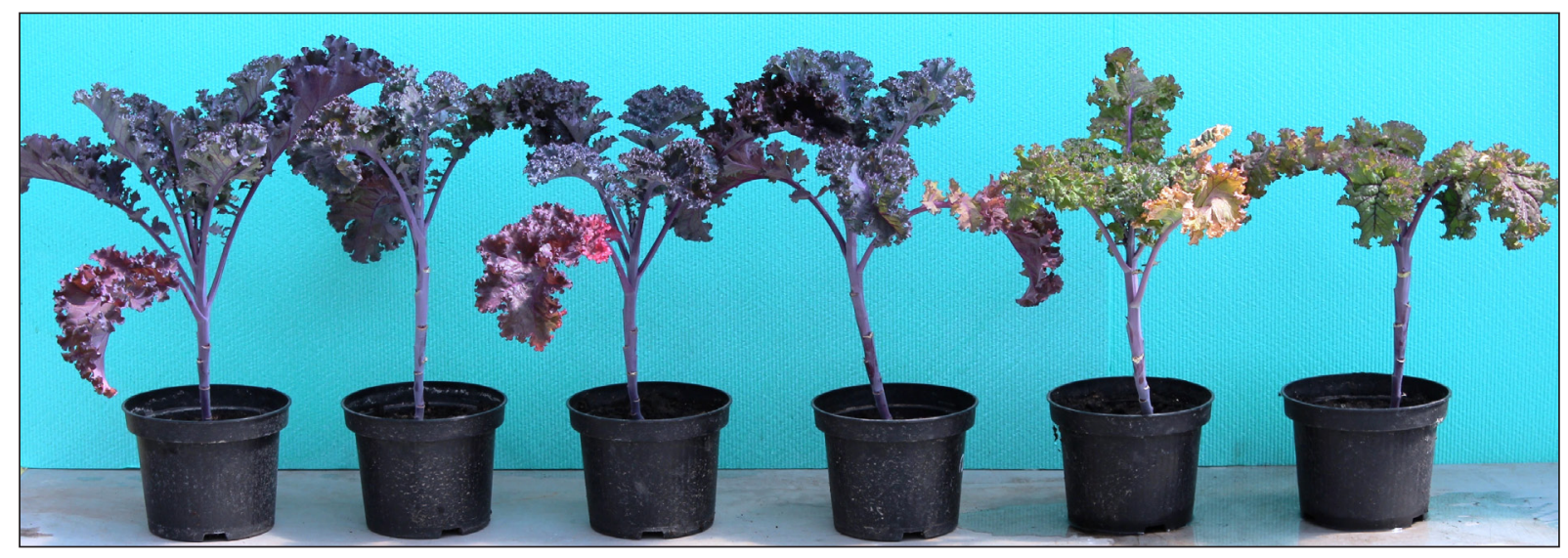

Figure 1. Effect of salinity on growth curly kale

(left to right: nontreated control, 50, 100, 200, 400, and $800 \mathrm{mmol} \cdot \mathrm{dm}^{-3} \mathrm{NaCl}$ ) 
Table 2. Effect of $\mathrm{NaCl}$ at concentrations of $0-800 \mathrm{mmol} \cdot \mathrm{dm}^{-3}$ on stomatal conductance $\left(g_{s}\right)$ and stomatal conductance rate to control (\%) in curly kale. Values are presented as the means \pm standard deviation

\begin{tabular}{|c|c|c|c|c|}
\hline \multirow{2}{*}{$\mathrm{NaCl}\left(\mathrm{mmol} \cdot \mathrm{dm}^{-3}\right)$} & \multicolumn{2}{|c|}{5 days after the stress cessation } & \multicolumn{2}{c|}{15 days after the stress cessation } \\
\cline { 2 - 4 } & $\begin{array}{c}g_{\mathrm{s}} \\
(\mathrm{mmol} \mathrm{m} \mathrm{s})\end{array}$ & $g_{\mathrm{s}}$ rate to control $(\%)$ & $\begin{array}{c}g_{\mathrm{s}} \\
(\mathrm{mmol} \mathrm{m} \mathrm{s})\end{array}$ & $\begin{array}{c}g_{\mathrm{s}} \text { rate to } \\
\text { control }(\%)\end{array}$ \\
\hline 0 & $30.9 \pm 1.47$ & 0.00 & $43.0 \pm 1.32$ & 0.00 \\
\hline 50 & $28.7 \pm 0.90$ & -7.12 & $35.0 \pm 2.65$ & -18.6 \\
\hline 100 & $26.8 \pm 2.76$ & -13.3 & $35.0 \pm 2.00$ & -18.6 \\
\hline 200 & $18.2 \pm 2.03$ & -41.1 & $33.6 \pm 4.71$ & -27.9 \\
\hline 400 & $16.3 \pm 1.30$ & -47.2 & $31.0 \pm 4.36$ & -34.4 \\
\hline 800 & $12.5 \pm 2.72$ & -59.5 & $28.2 \pm 0.93$ & -- \\
\hline $\mathrm{LSD}_{0,05}$ & 5.465 & -- & 8.291 & \\
\hline
\end{tabular}

Table 3. Effect of $\mathrm{NaCl}$ at concentrations of $0-800 \mathrm{mmol} \cdot \mathrm{dm}^{-3}$ on relative chlorophyll content (SPAD) and relative chlorophyll content rate to control (\%) in curly kale. Values are presented as the means \pm standard deviation

\begin{tabular}{|c|c|c|c|c|}
\hline \multirow{2}{*}{$\begin{array}{c}\mathrm{NaCl} \\
\left(\mathrm{mmol} \cdot \mathrm{dm}^{-3}\right)\end{array}$} & \multicolumn{2}{|c|}{5 days after the stress cessation } & \multicolumn{2}{|c|}{15 days after the stress cessation } \\
\cline { 2 - 5 } & SPAD & $\begin{array}{c}\text { SPAD rate to control } \\
(\%)\end{array}$ & SPAD & $\begin{array}{c}\text { SPAD rate to control } \\
(\%)\end{array}$ \\
\hline 0 & $43.2 \pm 1.11$ & 0.00 & $43.5 \pm 1.10$ & 0.00 \\
\hline 50 & $44.6 \pm 0.71$ & 3.24 & $37.8 \pm 2.01$ & -13.1 \\
\hline 100 & $43.4 \pm 1.25$ & 0.46 & $34.0 \pm 3.27$ & -21.8 \\
\hline 200 & $43.0 \pm 1.23$ & -0.46 & $30.8 \pm 1.42$ & -42.9 \\
\hline 400 & $37.5 \pm 1.14$ & -13.2 & $24.8 \pm 1.50$ & -57.5 \\
\hline 800 & $31.2 \pm 2.00$ & -27.8 & $18.5 \pm 0.64$ & -- \\
\hline $\mathrm{LSD}_{0.05}$ & 3.562 & -- & 5.086 & \\
\hline
\end{tabular}

had significantly lower leaf greenness index as compared with control, by 5.7 and 12 SPAD, respectively. After the next 10 days, chlorophyll content in curly kale leaves was reduced in all $\mathrm{NaCl}$ variants, and the changes were concentration dependent. Similar findings were published by Zheng et al. [2010], who investigated the seedlings of Brassica oleracea L. var. acephalea DC. and reported chlorophyll loss that increased with growing $\mathrm{NaCl}$ concentrations. Leaf greenness index markedly decreased in other salt treated ornamental plants, such as Calendula officinalis L., Calceolaria $\times$ herbeohybrida Voss [Fornes et al., 2007], Glandularia canadensis (L.) Nutt., Lantana montevidensis (Spreng.) Briq. [Niu et al., 2007], or Chrysanthemum ×morifolium 'Yellow Blush' [Lee and van Iersel, 2008]. According to the literature (Nandy et al., 2007; Jaleel et al., 2008), excessive amounts of salt may accumulate in chloroplasts and exert a direct toxic effect on photosynthesis through destabilization and destruction of protein complexes of photosynthetic pigments. Differences in chlorophyll content five and fifteen days after the last treatment can be explained by the fact that the time after which salt-related damage is visible depends on the rate of $\mathrm{Na}^{+}$ and $\mathrm{Cl}^{-}$ion accumulation and efficiency of their sequestration in cells and tissues [Munns, 2002].
Irrigation of 'Scarlet' curly kale with $\mathrm{NaCl}$ solutions significantly affected plant height in the concentration-dependent manner (Table 4). A substantial growth reduction due to salinity was observed in plants treated with 200,400 , and $800 \mathrm{mmol} \mathrm{NaCl} \cdot \mathrm{dm}^{-3}$. They were lower than the control plants by $21.9 \%, 27.9 \%$, and $34.4 \%$, respectively. Salt stress related growth inhibition was confirmed in several studies [Ibrahim et al., 1991; Valdez-Aguilar et al., 2009; Krzymińska and Ulczycka-Walorska, 2015; García-Caparrós et al., 2016; Salachna et al., 2016]. Salinity was reported to inhibit mitoses and elongation growth of cells and consequently reduce fresh and dry weight, especially of the above ground parts [Cassaniti et al., 2012].

In this study, 'Scarlet' curly kale grown under salt stress conditions had fewer leaves as compared with the control plants (Table 4). This relationship depended on $\mathrm{NaCl}$ concentration. The plants treated with the highest concentration of $\mathrm{NaCl}$, i.e. $800 \mathrm{mmol} \mathrm{NaCl} \cdot \mathrm{dm}^{-3}$ produced the lowest number of leaves. Reduced number of leaves in plants exposed to excessive salinity was also observed in such bedding plants as Coleus blumei 'Xenia Field' and Salvia splendens 'Flare Path' [Ibrahim et al. 1991]. 
Table 4. Effect of $\mathrm{NaCl}$ at concentrations of $0-800 \mathrm{mmol} \cdot \mathrm{dm}^{-3}$ on plant characteristics in curly kale. Values are presented as the means \pm standard deviation

\begin{tabular}{|c|c|c|c|c|c|}
\hline $\mathrm{NaCl}\left(\mathrm{mmol} \cdot \mathrm{dm}^{-3}\right)$ & $\begin{array}{c}\text { Plant height } \\
(\mathrm{cm})\end{array}$ & Number of leaves & $\begin{array}{c}\text { Leaf width } \\
(\mathrm{cm})\end{array}$ & $\begin{array}{c}\text { Leaf length } \\
(\mathrm{cm})\end{array}$ & Visual score \\
\hline 0 & $43.0 \pm 1.32$ & $18.7 \pm 1.53$ & $26.7 \pm 2.08$ & $10.2 \pm 0.46$ & $5.00 \pm 0.00$ \\
\hline 50 & $35.0 \pm 2.65$ & $16.7 \pm 0.58$ & $26.3 \pm 0.58$ & $9.03 \pm 0.50$ & $4.67 \pm 0.29$ \\
\hline 100 & $35.0 \pm 2.00$ & $15.0 \pm 1.00$ & $25.0 \pm 1.00$ & $8.27 \pm 0.25$ & $4.50 \pm 0.50$ \\
\hline 200 & $33.6 \pm 4.71$ & $15.0 \pm 1.73$ & $24.3 \pm 1.16$ & $8.60 \pm 0.36$ & $3.83 \pm 0.29$ \\
\hline 400 & $31.0 \pm 4.36$ & $15.3 \pm 0.58$ & $25.0 \pm 1.00$ & $8.27 \pm 0.25$ & $3.33 \pm 0.29$ \\
\hline 800 & $28.2 \pm 0.93$ & $14.0 \pm 0.00$ & $23.0 \pm 1.00$ & $7.83 \pm 0.29$ & $2.50 \pm 0.50$ \\
\hline $\mathrm{LSD}_{0.05}$ & 8.291 & 2.963 & 3.359 & 1.006 & 0.970 \\
\hline
\end{tabular}

The plants treated with $800 \mathrm{mmol} \mathrm{NaCl} \cdot \mathrm{dm}^{-3}$ produced the shortest leaves with the narrowest blades, as compared with other and non-treated control plants (Table 4). Adverse effects of strong salt stress on leaf surface were also reported in chrysanthemum [Lee and van Iersel, 2008] and Grewia tenax (Forssk.) Fiori [Saied et al., 2010]. Reduction in the leaf number and size in plants exposed to salinity causes a decrease in photosynthesis rate and depletion of energy resources necessary for plant growth and development [Kłosowska, 2010].

The study demonstrated that the visual score of the plants treated with 50 and $100 \mathrm{mmol}$ $\mathrm{NaCl} \cdot \mathrm{dm}^{-3}$ was not significantly different from that of the control plants (Table 4). A clear reduction of plant quality was observed after the application of 200,400 , or $800 \mathrm{mmol} \mathrm{NaCl} \cdot \mathrm{dm}^{-3}$, and the bonitation score decreased along with increasing $\mathrm{NaCl}$ concentration. The fact that 'Scarlet' curly kale growing in the presence of 50 and 100 $\mathrm{mmol} \mathrm{NaCl} \cdot \mathrm{dm}^{-3}$ retained its decorative properties suggests that this cultivar is moderately tolerant to soil salinity. However, this assumption requires further study. Plant response to salinity under controlled condition may be different from that in the field, and the differences are due to an interaction of many factors, such as climatic conditions, nutrient status or soil properties that modify plant tolerance to salinity [Wu et al., 1995; Munns and Termaat, 2002; Niu et al., 2007].

\section{Acknowledgements}

This study was supported by the Polish Ministry of Science and Higher Education, within the project UPB 518-07-014-3176-02/18 ZUT.

\section{REFERENCES}

1. Bach A. Pawłowska B. Pietrzak M. 2009. Zwalczanie skutków zimy. Zieleń Miejska, 1, 33-35.

2. Breś W., 2008. Czynniki antropopresji powodujące zamieranie drzew w krajobrazie miejskim. Nauka Przyr. Technol., 2,4, \#31.

3. Breś W., Kupska A., Trelka T. 2014. Response of scarlet sage and common sunflower plants to salinity caused by sodium salts. Folia Pomer. Univ. Technol. Stetin., Agric., Aliment., Pisc., Zootech., 315 (32), 5-14.

4. Cassaniti C., Romano D., Flowers T.J. 2012. The response of ornamental plants to saline irrigation water, irrigation - water management, pollution and alternative strategies. Edited by Iker GarciaGarizabal. InTech, 131-158.

5. Cassaniti C., Romano D., Hop M.E.C.M., Flowers T.J. 2013. Growing floricultural crops with brackish water. Environ. Exp. Bot., 92, 165-175.

6. Chen M., Yang Y.-J., Li H.-Y. 2011. Effect of $\mathrm{NaCl}$ stress on seed germination of ornamental kale. Northern Horticulture, 16.

7. Escalona A., Salas M.C., Coutinho C.D.S., Guzman M. 2013. How does salinity affect mineral ion relations and growth of Lobelia erinus for use in urban landscaping? J. Food Agric. Environ., 11 (2), 854-858.

8. Fornes F., Belda R.M., Carrion C., Noguera V., Garcia-Agustin P., Abad M. 2007. Pre-conditioning ornamental plants to drought by means of saline water irrigation as related to salinity tolerance. Sci. Hortic., 113 (1), 52-59.

9. García-Caparrós P., Llanderal A., Pestana M., Correia P.J., Lao M.T. 2016. Tolerance mechanisms of three potted ornamental plants grown under moderate salinity. Sci. Hortic., 201, 84-91.

10. Gibson J. L., Whipker B. E. 2001. Ornamental cabbage and kale cultivar comparison study: Growth characteristics and response to daminozide and uniconazole foliar sprays. HortTechnology, 11(3), 376-380.

11. Haghighi M., Kafi M., Pessarakli M., Sheibanirad A., Sharifinia M.R. 2016. Using kale (Brassica oleracea var. acephala) as a phytoreme- 
diation plant species for lead $(\mathrm{Pb})$ and cadmium (Cd) removal in saline soils. J. Plant Nutr., doi: 10.1080/01904167.2016.1161768

12. Hirvela S. 2014. Edible spots and pots: small-space gardens for growing vegetables and herbs in containers, raised Beds, and more. Rodale Books, 236.

13. Ibrahim K.M., Collins J.C. Collin H.A. 1991. Effects of salinity on growth and ionic composition of Coleus blumei and Salvia splendens. J. Hortic. Sci., 66 (2), 215-222.

14. Jaleel C. A., Sankar B., Sridharan R., PanneerselvamR., 2008. Soil salinity alters growth, chlorophyllcontent, and secondary metabolite accumulation in Catharanthus roseus. Turk. J. Bot., 32,79-83.

15. Kłosowska K. 2010. Reakcje roślin na stres solny. Kosmos, 3-4 (59), 539-549.

16. Krzymińska A., Ulczycka-Walorska M. 2015. The effect of sodium chloride on growth and quality of Plectranthus forsteri Benth. 'Nico'. J. Hort. Res., 23 (1), 17-20.

17. Lee M.K., van Iersel M.W. 2008. Sodium chloride effects on growth, morphology, and physiology of chrysanthemum (Chrysanthemum $\times$ morifolium). HortScience, 43 (6), 1888-1891.

18. Lewandowska A. 2000. Jarmuż. Polowa uprawa warzyw. Praca zbiorowa (red. Orłowski M.). Brasica Szczecin, 60-63.

19. Ma Q., Yue L.-J., Zhang J.-L., Wu G.-Q., Bao A.K., Wang S.-M. 2012. Sodium chloride improves photosynthesis and water status in the succulent xerophyte Zygophyllum xanthoxylum. Tree Physiol., 32 (1), 4-13.

20. Mansour M.M.F., Salama K.H.A., Allam H.Y.H. 2015. Role of the plasma membrane in saline conditions: lipids and proteins. Bot. Rev., 81 (4), 416-451.

21. Marschner, H. 1995. Mineral nutrition of higher plants (2nd ed.). Academic Press, New York.

22. Munns R. 2002. Comparative physiology of salt and water stress. Plant Cell Environ., 25, 239-250.

23. Munns R., Termaat A. 1986. Whole-plant responses to salinity. Funct. Plant Biol., 13(1), 143-160.

24. Munns R., Tester M. 2008 Mechanisms of salinity tolerance. Annu. Rev. Plant Biol., 59, 651-681 .

25. Murray M., Pizzorno J.E., Pizzorno L.U. 2005. The encyclopaedia of healing foods. Atria Books New York, United States, 210.

26. Nandy P., Das S., Ghose M., Spooner-Hart R., 2007. Effects of salinity on photosynthesis, leaf anatomy,ion accumulation and photosynthetic nitrogenuse efficiency in five Indian mangroves. Wetlands Ecol. Manage., 15, 347-357.

27. Niu G., Cabrera R.I. 2010. Growth and physiological responses of landscape plants to saline water irrigation: A review. HortScience, 45 (11), 1605-1609.

28. Niu G., Rodriguez D.S., Aguiniga L. 2007. Growth and landscape performance of ten herbaceous species in response to saline water irrigation. J. Environ. Hortic., 25 (4), 204-210.

29. Niu G., Rodriguez D.S., Starman T. 2010. Re- sponse of bedding plants to saline water irrigation. HortScience, 45, 628-636.

30. Parihar P., Singh S., Singh R., Singh V.P., Prasad S.M. 2015. Effect of salinity stress on plants and its tolerance strategies: a review. Environ. Sci. Pollut. R., 22 (6), 4056-4075.

31. Pląskowska E. 2010. Miejskie tereny zielone - zagrożenia. Praca zbiorowa (red. E . Pląskowska). Wyd. UP we Wrocławiu.

32. Saied A.S., Sohail M., Gebauer J., Buerkert A. 2010. Response of Grewia tenax (Forssk.) Fiori to NaClinduced salinity Eur. J. Hortic. Sci., 75 (1), 42-50.

33. Salachna P., Piechocki R. 2016. Effects of sodium chloride on growth and mineral nutrition of purpletop vervain. J. Ecol. Eng., 17(2), 148-152

34. Salachna P., Piechocki R., Zawadzinska A., Woskowiak A. 2015. Response of speckled spur-flower to salinity stress and salicylic acid treatment. J. Ecol. Eng., 16 (5), 68-75.

35. Salachna P., Zawadzińska A., Podsiadło C. 2016. Response of Ornithogalum saundersiae Bak. to salinity stress. Acta Sci. Pol., Hortorum Cultus 15(1), 123-134.

36. Sonneveld C., Baas R., Nijssen H.M.C., De Hoog J. 1999. Salt tolerance of flower crops grown in soilless culture. J. Plant Nutr. 22 (6), 1033-1048.

37. Sun Y., Niu G., Perez C. 2015. Relative salt tolerance of seven Texas superstar ${ }^{\circledR}$ perennials. HortScience, 50 (10), 1562-1566.

38. Valdez-Aguilar L.A., Grieve C.M., Poss J., Mellano M.A. 2009. Hypersensitivity of Ranunculus asiaticus to salinity and alkaline $\mathrm{pH}$ in irrigation water in sand cultures HortScience, 44 (1), 138-144.

39. Veatch-Blohm M.E., Chen D., Hassett M. 2013. Narcissus cultivar differences in response to saline irrigation when application began either pre- or postemergence. HortScience, 48 (3), 322-329.

40. Villarino G.H., Mattson N.S. 2011. Assessing tolerance to sodium chloride salinity in fourteen floriculture species. HortTechnology, 21, 539-545.

41. Watson B. 1996. Taylor's guide to heirloom vegetables. Boston, Houghton Mifflin. 200.

42. Wu L.J., Chen H., Lin P., Van Mantgem Harivandi M.A., Harding J.A. 1995. Effects of regenerant wastewater irrigation on growth and ion uptake of landscape plants. J. Environ. Hort., 13(4), 92-96.

43. Wu S., Sun Y., Niu G. 2016. Morphological and physiological responses of nine ornamental species to saline irrigation water. HortScience, 51 (3), 285-290.

44. Zhang L., Ma H., Chen T., Pen J., Yu S., Zhao X. 2014. Morphological and physiological responses of cotton (Gossypium hirsutum L.) plants to salinity. PLoS ONE 9(11): e112807. doi:10.1371/journal.pone.0112807.

45. Zhao H.Y., Li Y.Y. 2011. Ornamental characteristics and gardening applications of kale (Brassica oleracea var. acephala). Heilongjiang Agricultural Sciences, 2, 39.

46. Zheng F.-X., Wei M., Mu T.-S. 2010. Effects of $\mathrm{NaCl}$ stress on physiological and biochemical indices in ornamental kale. Northern Horticulture, 17. 